This is an Accepted Manuscript of an article published by Taylor \& Francis in Atlantic Studies in 2012, available online: http://dx.doi.org/10.1080/14788810.2012.637000 It was part funded by the AHRC (Grant Ref. AH/I027290/1)

\title{
Gluttony, excess, and the fall of the planter class in the British Caribbean
}

Christer Petley

University of Southampton

Food and rituals around eating are a fundamental part of human existence. They can also be heavily politicized and socially significant. In the British Caribbean, white slaveholders were renowned for their hospitality towards one another and towards white visitors. This was no simple quirk of local character. Hospitality and sociability played a crucial role in binding the white minority together. This solidarity helped a small number of whites to dominate and control the enslaved majority. By the end of the eighteenth century, British metropolitan observers had an entrenched opinion of Caribbean whites as gluttons. Travelers reported on the sumptuous meals and excessive drinking of the planter class. Abolitionists associated these features of local society with the corrupting influences of slavery. Excessive consumption and lack of self-control were seen as symptoms of white-creole failure. This article explores how local cuisine and white creole eating rituals developed as part of slave societies and examines the ways in which ideas about hospitality and gluttony fed into the debates over slavery that led to the dismantling of slavery and the fall of the planter class.

Keywords: planters; Caribbean; Jamaica; food; drink; gluttony; abolitionism

Email: c.petley@soton.ac.uk 
In 1802, Maria Skinner Nugent remarked that white men in Jamaica "eat like cormorants and drink like porpoises." ${ }^{\prime 1}$ She recorded her thoughts in an entry to the detailed journal that she kept during her four-year stay in Jamaica with her husband, George Nugent, the Lieutenant Governor of the island. Her depictions of white-creole gluttony were characteristic of wider disdain for the society she encountered in Jamaica. To Nugent, that society's other excesses included the negative effects of slaveholding on white creole behavior and the demoralizing influence of loose sexual conduct. By the beginning of the nineteenth century, such attitudes were common; and they lived on. For example, Nugent's words were quoted a hundred and sixty years later by the West Indian writer and commentator V. S. Naipaul in his own travelogue of a trip to Jamaica. Naipaul proclaimed that in the Caribbean "slavery and latifundia created only grossness, men who ate 'like cormorants' and drank 'like porpoises'," parts of "a society without standards, without noble aspirations, nourished by greed and cruelty." ${ }^{2}$ His echo of Nugent represents the enduring image of the British-Caribbean planter class as a greedy and brutal bunch, and it illustrates the close association of planters' bodily practices, such as eating and drinking, with moral corruption, social failings, and cultural destitution in the Caribbean colonies, an association that played an important role in the fall of the planter class from their mid-eighteenth-century position of wealth and power.

Focusing on food, drink, and the rituals that surround them, this article discusses how Jamaican planters ended up with reputations as men with excessive and gluttonous appetites and why those reputations mattered. It explores the social role of food and drink in Caribbean slave societies, with a particular focus on Jamaica, before discussing changing British attitudes towards the planters and the ways in which these were reflected in Nugent's travel journal. The approach is informed by the work of such scholars such as Linda Colley, Catherine Hall, and David Lambert, who have presented the emergence of new forms of British national identity and disputes about the ideal 
modes of behavior for white colonials as central elements in the debate over slavery. ${ }^{3}$ It is also informed by recent suggestions, particularly by Christopher Leslie Brown and Dror Wahrman, that the American Revolutionary War marked a critical moment in the formation of the antislavery movement and the crystallization of new forms of British metropolitan selfhood. ${ }^{4}$ Exploring these themes, the article aims to shed new light on the struggle over slavery, the decline of the planters, and shifting ideas about the place of the Caribbean in the wider British empire at the end of the long eighteenth century.

As Mary Louise Pratt notes, "empires create in the imperial centre of power an obsessive need to present and re-present its peripheries and its others continually to itself." The case of British-Caribbean planters is particularly interesting in this regard because they were a truly liminal group, perpetually half-in and half-out of the boundaries of British identity as inscribed by metropolitan opinion makers. For much of the eighteenth century, up to and including the 1770s, they occupied an ambiguous place in the British imagination, generally neither loved nor loathed. Thereafter, their reputation plummeted, as metropolitan attitudes towards slaveholding hardened. During the period between the 1780 s and the 1840 s, abolitionist campaigns represented the greatest challenge to planter economic and political power. Critical appraisals of white colonial practices presented planters as subjects who fell firmly outside the pale of proper British behavior. Even those who remained ambivalent about slavery could see Caribbean colonial society as flawed and in need of reform, and consequently planters struggled to represent themselves as productive and useful members of the empire. This epitomized the cultural and political fall of the planter class, a fall that was part of a late-eighteenth-century reformulation of British identity, as Britons sought to redefine nation and empire in the context of revolutionary changes at home and overseas. 
Among white colonists, there appears to have been nothing very different about the basic mechanics of serving and eating food in the West Indies compared to the metropole or North America. Probate inventories from early-nineteenth-century Jamaica show that planters and other white men of property owned furniture, such as mahogany tables and chairs, as well as fine dinner services, crockery, and cutlery. ${ }^{6}$ Caribbean eating and serving methods deviated little from metropolitan norms, but food and drink had greater significance in white creole culture than in the metropole. Writing in 1793, one commentator noted that it was "no uncommon thing to find, at the country habitations of the planters, a splendid sideboard loaded with plate, and the choicest wines, a table covered with the finest damask, and a dinner of perhaps sixteen or twenty covers," all laid on in a relatively modest house. ${ }^{7}$

In Jamaica by the early nineteenth century, white colonists numbered about 20,000 , around five percent of the island's overall population, of which enslaved people, imported from Africa or descended from Africans, made up by far the largest section: about 350,000 at the beginning of the nineteenth century. ${ }^{8}$ The demographic situation was similar across the British West Indies, which shared the general characteristics of what Trevor Burnard has termed a "failed settler society," inhabited by white colonists unable to reproduce their numbers and reliant on importations of African slaves into an unstable, violent, and deadly physical and social landscape. ${ }^{9}$ Unlike North American colonies during the eighteenth century, or the colonies of white settlement, such as Canada, Australia, and New Zealand, in the nineteenth century, the Caribbean was not attractive to European migrant families. As such, the region earned a reputation in the metropole as a place stalked by death, characterized by an imbalance between the number of men and women, where normal family and social relations had been abandoned in the pursuit of the vast profits that could be won from slavery and plantation agriculture. ${ }^{10}$ 
Throughout this region, the male-dominated white minority stuck together. Partly, this was to achieve a sense of security, faced with the ever-present prospect of a slave uprising, but whites also had other reasons to forge a corporate identity. Slaveholding was commonplace, and non-slaveholding white men tended to find employment managing slaves on the plantations. The identities of white men were therefore intimately linked to their status as a privileged master class in an unequal society. Colonists came to recognize that they had to bury their differences in order to protect their safety, livelihoods, and prestige. ${ }^{11}$ The consequent culture of solidarity was one of the most effective weapons that they deployed to overcome uprisings, keep order across society, and extract labor from enslaved workers. ${ }^{12}$

"White unity," as Burnard has observed, "was fostered by an all-embracing cult of hospitality." 13 This phenomenon meant that in rural parts of Jamaica white travelers could expect to receive food, drink, and a bed for the night in the houses of other white colonists. ${ }^{14}$ In 1790, the planter William Beckford noted this "general hospitality" which was "observed to reign all over the island." 15 Another commentator concurred, observing that it was "quite customary for travelling people to call on each other, though strangers, for refreshment for themselves, servants, and horses, and that too without any ceremony or formality." 16 These habits persisted into the nineteenth century, and observers judged them to be universal "among all ranks, professions, and conditions." In 1831, one local was so indignant about having been turned away by the overseer of a sugar estate when in need of a bed for the night that he took the time to write about it to a local newspaper, which commented that it was "the only instance of the want of Jamaica hospitality of which we ever heard.",17

Collective dining brought white men together in performed reiterations of their solidarity. Colonists met to eat and drink on a regular basis. On rural properties they passed their evenings "in conversation, smoking, and drinking." ${ }^{18}$ Dinner parties, 
drinking sessions, and informal visits formed a part of the social fabric of plantation Jamaica, and white colonists, according to one commentator, were "bons vivants, even the lowest tradesmen drinking wine after dinner, besides rum, or brandy and water, in the afternoon." ${ }^{\prime 19}$ As one resident of Jamaica explained, there were many different occasions for white men to get together to eat and drink:

Besides numerous private parties, there are frequent tavern dinners on various public occasions; as freemasons' dinners (there are no less than seventeen lodges in the island), military dinners, vestry dinners, grand jury dinners, peace dinners, king's birth-day dinners, governor's dinners (while that officer performs his military tour), victory dinners, \&c. \&c. On these occasions no expense is spared to render the entertainment costly and splendid. Every luxury is catered up for the purpose, and copious libations of various wines, and other good things, are poured forth to the jolly god of good fellowship. ${ }^{20}$

Conviviality and drinking was clearly especially important after public events such as court days, elections, and militia musters, when white men gathered together in the parish towns and review grounds around the island to execute their civic duties and parade their privileged status in ritualized acts of white entitlement. ${ }^{21}$

Generally speaking, shared meals were sites of male bonding. In large part, this was because white men outnumbered white women in the plantation societies of the British West Indies. The fact that there were 613 white men and 387 white women living in the Jamaican parish of St. James in 1774 helps to illustrate this disparity, which appears to have been even more pronounced in some other parts of the island. ${ }^{22}$ However, there was a female presence in most colonial households, because most male colonists quickly found a free-colored or enslaved mistress, colloquially known as a "housekeeper." 23 Nevertheless, because these arrangements were viewed by many in the metropole as symptomatic of the failure of correct domestic arrangements to take root in 
the Caribbean, mistresses and mixed-race children came to be awkward facts of colonial life for many planters. ${ }^{24}$ One observer of local mores warned that it could injure a white man's reputation to be seen with his colored mistress "in a public place by day." 25 According to Robert Renny, such women performed the duties of de-facto wives, "except that of presiding at table, when there are strangers present," during which times they dined separately from the main group. ${ }^{26}$ In the plantation great houses of Jamaica, therefore, dining around the master's table was probably often confined to maledominated white parties, particularly when guests were present.

Whether served by a housekeeper or by enslaved domestics, meals in Caribbean slave societies was almost always prepared by enslaved people and in some large measure produced by and procured from enslaved workers. ${ }^{27}$ Across the British Caribbean, unequal relationships of dependency between masters and slaves were evident in dining practices, and the very act of white men freely satisfying their appetites in rituals of collective consumption worked to underline the fact that enslaved people could be less sure of their own sustenance. In this, as in other areas of their lives, slaves faced insecurity. There was famine in Jamaica during the 1780s, and in more stable times, as Mary Turner notes, slaves still had an "uncertain and limited command of subsistence." Across the Caribbean enslaved people were forced to use a variety of tactics to maximize the amount of food that they could grow for themselves on provision grounds and gardens or that slaveholders made available to them from other sources. ${ }^{28}$ This struggle was largely rooted in the economics of plantation production: masters wanted to get the most possible work from slaves at the lowest possible cost. It also reinforced racialized social boundaries between black and white. Jamaican modes of eating and drinking were shaped at all levels by the inequalities inscribed between enslaved blacks and free whites in a slave society. Enslaved people had to work and bargain hard if they wanted to eat; whites simply had to turn up at one another's houses. 
II

White West Indians had a well-earned reputation across the British Atlantic world as people with large appetites and strong thirsts. This formed one part of a broader set of metropolitan ideas about the character of plantation societies in the Americas. From the time of the formation of the plantations in the seventeenth century, the Caribbean had a reputation in the British Isles as an aberrant and corrupting place, and eighteenthcentury Britons worried about the behaviors and identities of those most intimately integrated into culturally heterogeneous societies at the margins of empire. ${ }^{29}$ As Kathleen Wilson observes, to many eighteenth-century Britons it seemed that "the national character, acquired through propinquity, could when removed from the structures of civilized life quickly give way. ${ }^{, 30}$ Roxann Wheeler notes that the commercial world of the British empire entailed a wide range of cultural exchanges with non-British people and adaptations to new environments and institutions, nowhere more so than in the Caribbean, where "many observers concluded that Englishness showed alarming evidence of degeneration and vulnerability." ${ }^{31}$ Slaveholding and concubinage were taken as the main signs of divergence from British norms, but drunkenness and gluttony were also symptoms of creole decadence.

Despite the poor cultural reputation of white Caribbean creoles, several rich planters achieved considerable prominence and power in the metropole. The best known example is Alderman William Beckford of London. Richard Sheridan describes the Beckford family as "the kings of Jamaica," whose West Indian fortunes allowed them fame and influence at the heart of the empire, and there were other less glittering examples of men propelled by fortunes derived from Caribbean slavery into British high society and public life. ${ }^{32}$ However, while some West Indians managed to accrue vast wealth and occupy positions of influence, the planters were never able to convince 
metropolitan Britons that they lived wholesome lives. Economic success and political influence were the hallmarks of their golden age, while perceived cultural decadence remained their Achilles heel. ${ }^{33}$

Like the Nabobs of the East, West Indian planters carried with them the whiff of scandal. ${ }^{34}$ For example, Richard Cumberland's popular and successful play The West Indian, which opened in the West End in 1771, attempted to present its main character in an agreeable light but could not avoid strong allusions to his many eccentricities and flaws. The protagonist of the drama is the West-Indian plantation owner, Belcour, returning to London from Jamaica. Before his arrival on stage, other characters voice concerns about "this creolean," "an outlandish spark," who has brought with him to England a small menagerie of tropical animals: "two green monkeys, a pair of grey parrots, a Jamaica sow and pigs, and a Mangrove dog. ${ }^{, 35}$ Servants prepare a lavish dinner with which to greet him, and one exclaims that their expected guest "has rum and sugar enough belonging to him, to make all the water in the Thames into punch."36 Before his entrance into the play, therefore, the eponymous white West Indian is associated with the exotic and the foreign, as well as with wealth, drink, and heavy eating. These themes are sustained in the lines that Cumberland gives Belcour to speak. "My happy stars have given me a good estate, and the conspiring winds have driven me here to spend it," he professes, before confessing "my passions are my masters; they take me where they will; and oftentimes they leave to reason and to virtue nothing but my wishes and my sighs." 37

In 1807, over three decades after writing The West Indian, Cumberland reminisced that in his plays he had wanted to explore the characters of persons, who had been usually exhibited on the stage, as the butts for ridicule and abuse, and endeavoured to present them in such lights, as might tend to reconcile the world to them, and them to the world. 
To his West Indian, Cumberland claimed to have "devoted a generous spirit, and a vivacious giddy dissipation," admitting "I could not keep consistency of character without a mixture of failings." ${ }^{38}$ It was therefore still possible in 1771 to present a white West Indian in a favorable light in a popular West-End play, but it was not feasible to present him without the array of flaws that theatre-goers would expect to find in such creole personalities. Included among these were strong appetites and a lack of selfcontrol.

Travelers to the West Indies from the metropole also noted such flaws, although before the advent of the abolition movement, they were frequently forgiving of white creolean difference. Janet Schaw, for example, saw slaveholders, slavery, and the slave trade all in a positive light and was impressed by the hospitality that she received on her visits to Antigua and St. Kitts between 1774 and $1775 .{ }^{39}$ At one plantation, she had a "family dinner, which in England might figure away in a newspaper, had it been given by a Lord Mayor, or the first Duke of the kingdom." Such extravagance clearly impressed her, however, and she continued: "Why should we blame these people for their luxury? since nature holds out her lap, filled with every thing that is in her power to bestow, it were sinful in them not to be luxurious." ${ }^{, 40}$ She reveled in white West Indian dining. Schaw enthusiastically discussed local foods, particularly fish and fruit, as well as commenting on the good manners and taste of her hosts. ${ }^{41}$ She also thought the men of Antigua "the most agreeable creatures I ever met with, frank, open, generous, and I dare say brave." Their most conspicuous failing was "the indulgence they give themselves in their licentious and even unnatural amours," by which Schaw referred to relations between white men and non-white women, but she even downplayed this critique of planter behavior, conceding "they are mortals, and as such must have their share of failings." 42 
In the 1770s, therefore, British writers produced ambivalent portraits of white West Indians and their behavior, commenting on their perceived qualities as well as on their shortcomings. The comedy of Cumberland's play hinged upon Belcour's voracious sexual appetite but ended with the West Indian happily married and reconciled to his English companions. And, as Wheeler notes, one of the staunchest defenders of British slaveholders, the outspoken and influential planter-politician Edward Long, tempered his praise of white creoles with criticism. ${ }^{43}$ Writing in 1774 , Long highlighted the virtues of white creoles, claiming they displayed "noble and disinterested munificence," and he also remarked on their flaws, which included indolence, lack of chastity, "sudden transports of anger," and inclinations toward "expensive living, costly entertainments, dress, and equipage." To Long though none of this marked white Caribbean colonists out as unusual; they were simply - as he put it - "subject to frailties in common with the rest of mankind." In this formulation, which bears much in common with Cumberland's characterization of Belcour, white West Indians had "foibles in their disposition" which might be tolerated or ironed out without a root and branch reform of the colonial system. ${ }^{44}$

Before the 1780s, many metropolitan Britons disdained the wealth and ostentation of those planter families who had made spectacular fortunes and returned in glory to the metropole. They also criticized the behavior of white creoles, but this did not amount to a thoroughgoing attack on the planter class. As Christopher Leslie Brown argues, the impulse to criticize slaveholders "was tempered by an almost complete acceptance of the value of slavery to the colonies and to the empire." ${ }^{45}$ The planters were a source of worry, but even with their glutinous appetites, sexual incontinence, and violent tempers, this group were troublesome curiosities to some, flawed but valued nouveaux riches to others, and rarely seen as posing a serious problem. 
This changed quickly during the 1780 s as examples of transgressive behavior, once "widely entertained and tolerated," came to be seen as something more sinister: "a charged political challenge." ${ }^{46}$ Dror Wahrman's suggestion that the rise of abolitionism was intertwined "with the increasing essentializing of race and of identity" on both sides of the debate is relevant here because abolitionism from the 1780s onwards sought to impose on the colonies particular modes of behavior, rejecting the shortcomings of their white inhabitants not as troublesome eddies in a fluid transatlantic British culture but as base cracks in the very foundations of national identity. ${ }^{47}$

There were, of course, many causes for the transformations of British attitudes towards slaveholders, but as Brown has convincingly argued, the American Revolution appears to have been a fulcrum for change that allowed an abolition movement opposed to the practices and interests of the planter class to emerge and succeed. ${ }^{48}$ In broad terms, during and after the American War, British ministers continued to promote policies that would bring the expanding empire more closely under control by Westminster, and the rise of abolitionism (along with attempts to regulate the East India Company) was congruent with policies that sought to centralize imperial governance, imposing reforms on the colonial periphery from the imperial centre. ${ }^{49}$ More precisely, the American War halved the number of slaves in the empire and meant that, when the attack on slavery came, the West Indian lobby in London was without slaveholding colonial allies from North America. ${ }^{50}$ These changes helped provide a context in which an attack on the planters and their practices could enjoy success.

Moreover, during the conflict, metropolitan Britons became used to criticizing white colonists, picking up on slavery as an important marker of American difference, and as Troy Bickham notes war with America "accelerated the creation of a nation of imperial critics," informed about problems in the colonies and prepared to propose reforms. ${ }^{51}$ Wahrman goes further still, arguing that "a conflict that was seen as a civil 
war forced people to reflect - often with considerable apprehension - on their understandings of identity." 52 Questions about whether this was "a civil war between Englishmen" or "a war with aliens" helped usher in "the swift re-anchoring of notions of personal identity in what may be seen as more 'modern', essentializing foundations." 53 This had profound implications for metropolitan notions of Britishness and nationhood, which became more fixed, more firmly rooted in the morals and mores of Britons in the British Isles, and less accommodating of the sorts of divergences from the metropolitan norm indulged in by colonial Caribbean slaveholders. ${ }^{54}$

As the boundaries of Britishness tightened, planters in the tropics, who could once have prevailed on Britons at home to forgive them their eccentricities and accept them as a useful part of a wider British family, now faced intractable problems: an identity crisis. People in the metropole cast critical eyes across the Atlantic at colonial societies, and no matter how secure white creoles felt in their own sense of Britishness, metropolitan Britons noticed the differences of white colonists in the Caribbean no longer as mere foibles but as fundamental failures of character that called for swift reform and - since white creoles seemed too far corrupted to do it themselves - for direct imperial interventions. ${ }^{55}$

These changes helped to create a climate of opinion in which the abolitionist campaign, initiated by evangelical Anglicans like Granville Sharp, James Ramsay, William Wilberforce, and Thomas Clarkson, could gain public sympathy and support. The beginning of their campaign against the slave trade triggered what Catherine Hall has described as a "war of representation" that involved abolitionists working to present the Caribbean as a place governed by irreligion, greed, sin, and violence. The planters responded by arguing that the slave colonies were economically productive, that enslaved people were not worse off than workers elsewhere, and that white colonists were hard-working and patriotic members of the empire. ${ }^{56}$ 
Slaveholders living in the Caribbean came off particularly badly in the drawn out struggle to represent slavery to British audiences. As Nicholas Draper has argued, those who chose to live as absentees in the metropole were able to hide their status as slave-owners and were not directly involved in the day-to-day brutalities of plantation management; they easily assumed "alternative identities" and positioned themselves as genteel men of property rather than as rough and ready colonists. ${ }^{57}$ Those in the colonies did not have that option, and between the 1780s and the 1830 s their reputation in the metropole plummeted. Critics focused on the brutalities associated with the treatment of enslaved people, but they also picked up on creole sexual behavior, disdaining colonists' relations with women of color and their avoidance of marriage; and they agonized over white West Indian attitudes towards religion, decrying the planters' rejection of Nonconformist missionaries who went to the Caribbean to baptize enslaved people and spread Christianity. In the new cultural climate that emerged in the 1780s, therefore, even those Britons who found themselves undecided on the rights and wrongs of slave trading or slaveholding could find much to disapprove of in Caribbean white creole society. ${ }^{58}$

\section{III}

Those seeking to defend the planters in the abolition debates saw the famous generosity of white colonists as a valuable weapon in their armory. "In no part of the globe," wrote Bryan Edwards, "is the virtue of hospitality more generally prevalent, than in the British Sugar Islands," where the "gates of the planter are always open to the reception of his guests," and to "be a stranger is of itself a sufficient introduction." ${ }^{, 59}$ Edwards was one of the most eloquent defenders of slavery, and American and British authors plagiarized, paraphrased, and echoed his words, to the point that the idea that the WestIndian planter was "eminent for hospitality, distinguished by vivacity, and nobly 
generous" became a running cliché. ${ }^{60}$ Renny echoed these sentiments in his 1807 History of Jamaica. "For hospitality, the inhabitants of Jamaica are honorably distinguished, and cannot be sufficiently praised," he claimed, noting that this was confirmed by "all writers on the subject," shedding a "pleasing lustre" over the "whole conduct" of the white inhabitants. ${ }^{61}$

With such comments, proslavery writers sought to rescue the waning reputation of white West Indian colonists by providing an attractive image of Caribbean slave societies. Hospitality, after all, was a fundamental element of gentility. They picked up on older ideas about the warm-hearted openness of West Indian whites, attempting to repeat Cumberland's maneuver of showing white slaveholders of the Caribbean as sympathetic characters, as transplanted Englishmen, albeit with subtle, but occasionally pleasing, differences to metropolitan Britons.

They achieved little success. Abolitionists pointed to the inconsistencies in colonial hospitality. Claims that the "whole conduct" of white Jamaicans was marked by benevolence were routinely dismissed by abolitionist narratives about the wrongs that this group committed against enslaved people. "Slavery, in its mildest shape, has something dangerous and threatening to virtue," thought James Ramsay, who argued that slavery encouraged masters to become tyrants, untrammeled by self-restraint, who licentiously indulged themselves in cruelty and sensuousness to the detriment both of enslaved people and their own self interest. ${ }^{62}$ Consistent with this vein of criticism, Ramsay also described a colonist who "by too great hospitality" had fallen into debt and noted that such exorbitant entertaining was "an excess common enough in the West Indies." 63 The self-inflicted wounds of luxury and pride were therefore to be found not only in master slave relations but also in other quarters of colonial life, including hospitality and entertaining. 
In these ways, abolitionists presented slavery as part of a colonial social and economic system that was flawed in general and fundamentally immoral. Thomas Clarkson observed that the slave trade allowed the planter to replace enslaved workers killed by overwork and mistreatment, making him "the tyrant and destroyer" of his own slaves. ${ }^{64}$ William Wilberforce argued that in order to support their proprietors' "liberal and hospitable habits," plantation managers were persuaded to overwork and underfeed enslaved laborers in an unsustainable practice of "murder added to ruin." 65 The benevolent generosity associated with the "virtue of hospitality" was thereby exposed as another symptom of the planters' excessive, uncontrolled, and self-defeating behavior. Maria Nugent was one of the most observant of those critics who encountered Caribbean creole society at first hand during the period of the abolition debates. Arriving in Jamaica in July 1801, she was plunged into island high society. As the wife of the governor, she was far from a "typical" traveler, but her journal offers a unique insight into how a member of the metropolitan social elite saw Jamaican society at this critical moment. ${ }^{66}$ Nugent had much sympathy for several of the white planters she met but offered a coruscating critique of creole society in general, and her writing reflects the new, harder, attitude towards British identity that had developed after the American War.

On her first morning in the Governor's mansion in Spanish Town (which was known as the Kings House) Nugent was greeted by "a large party of gentlemen" at breakfast, including the outgoing Governor and Commander in Chief of the colony, Alexander Lindsay, Lord Balcarres. Later that day, she found "a numerous party assembled in the drawing room" but "only two ladies." Four days later her husband, George Nugent, was sworn in as Governor and given a public dinner in King's House. On this grand state occasion, the new Governor's wife ate with 40 women in the ball room; her husband "had three or four times that number with him" where he dined with 
the men in the larger Egyptian Hall. ${ }^{67}$ Such comparative lack of white female company was to be one of Nugent's bugbears in Jamaica, and she very quickly heard from white women "strange stories of the influence of the black and yellow women" and about the prevailing custom of concubinage, a custom that came to appall her as much as anything else she encountered in Jamaica, including the institution of slavery. ${ }^{68}$

Divergent methods of eating also occupied her attention. She soon settled into the pattern of rising early (usually between 5 and 6), followed by breakfast, a substantial "second breakfast" in late morning, and an early evening dinner. On her second day she noted, with relief, that Jamaicans did not have late suppers and, with disgust, that Balcarres had not only unwashed hands and dirty fingernails but also "an extraordinary propensity to dip his fingers into every dish." ${ }^{, 69}$ It is possible that eating without cutlery was a fairly common Jamaican practice. Colonists owned knives and forks but they also had items like "mahogany hand wash stands," "wash hand basins," and "finger basins" among their tableware, indicating that they washed their hands during the course of a meal. ${ }^{70}$ The outgoing lieutenant governor had possibly been creolized in this regard by his six years in Jamaica. Even before venturing from the King's House into the wider world of Jamaican slave society, therefore, Nugent began to notice in Balcarres some of the creolean "foibles," rapidly being redefined by hostile critics as vices, which set long-term inhabitants and creolized sojourners apart from metropolitan Britons. ${ }^{71}$

The most obvious vice of white Jamaicans was slaveholding, but Nugent was ambivalent about this. She spent her first morning "much amused," looking out of her window in King's House, "seeing the black population, and the odd appearance of everything.,"72 A week later she reflected "all night on slavery," concluding that the "want of exertion" on the part of domestic slaves in the gubernatorial mansion "must proceed from that cause." She gathered the enslaved people of the housekeeping staff together and promised to show them "every kindness and indulgence."73 Nugent wanted 
to send a copy of one of the catechisms that she created for her enslaved servants to William Wilberforce, whose work she read while living in Jamaica. ${ }^{74}$ She also listened at length to planters talk about slavery and the management of enslaved workers. In the first year of her stay in Jamaica, she was convinced that William Mitchell, one of the richest and most successful planters of his generation, was a "very vulgar, yet a very humane man" who treated his enslaved workers "kindly.",75 Towards the end of her time on the island, another leading planter, Samuel Vaughan, discussed with her the benefits of converting enslaved people to Christianity, which he claimed made them "sober, quiet, and well behaved." ${ }^{, 76}$ Nugent therefore read Wilberforce, but she was also influenced by men like Mitchell and Vaughan.

Vice, immorality, and excess were the main flaws in colonial society so far as Nugent was concerned, and nowhere was this behavior more often on open display than at mealtimes. In February of 1802, Governor Nugent began an inspection of Jamaica's defenses, including its local militia companies, which took his entourage on a circumnavigation of the island and on a crash course in white-creole hospitality. On the morning before one militia review, the Nugents went to William Mitchell's plantation, Bushy Park, where they "breakfasted Creole style" on cassava cakes, "chocolate, coffee, tea, fruits of all sorts, pigeon pies, hams, tongues, rounds of beef, \&c." Mitchell's delight, wrote Nugent, "is to stuff his guests, and I should think it would be quite a triumph to him, to hear of a fever or apoplexy, in consequence of his good cheer." After the review, the Nugents sat down to a "magnificent second breakfast," which prompted Maria to quip that "the business of ménage, or eating and drinking, was better understood than military tactics." Later that day, they had "a profuse dinner." Nugent proclaimed she had never seen "such eating and drinking," reflecting on the "loads of all sorts of high, rich, and seasoned things, and really gallons of wine and mixed liquors as they drink!" She concluded that "it was all as astonishing as it was disgusting." 
Clarendon, for the next review, the Nugents were greeted with a "loaded table," and within the week were watching the Vere militia, grappling with "a profuse breakfast," followed by "an immense dinner, with all the gentlemen of the militia."78 Towards the end of the month, they were back in the company of William Mitchell and "an abundant creole breakfast.",79

In March, the Nugents' "grand tour” of Jamaica's military and culinary highlights began in earnest. They stayed first at a property of Simon Taylor, one of the richest planters in the Caribbean. "A most profuse and overloaded table" awaited them, replete with "a shoulder of wild boar stewed, with forced meat, \&c. as an ornament to the centre of the table." Taylor took them to a number of properties that he owned or managed along the coastal route from St. Andrew to St. Thomas in the East. On 10 March, they ate a dinner at Golden Grove plantation, "even more profuse than usual" and consisting of a "great variety of fish, barbecued hog, fried conchs, \&c." 80 The next day, after breakfast, they arrived at nearby Holland estate (to a substantial second breakfast). ${ }^{81}$ In the evening there was a dinner "really so profuse" that Nugent decided to describe it in detail. It consisted of a first course "entirely of fish, excepting jerked hog," as well as "a black crab pepper-pot" (for which Nugent asked the recipe), followed by a second course of "turtle, mutton, beef, turkey, goose, ducks, chickens, capons, ham, tongue, crab patties, \&c. \&c. \&c." The final course was “composed of sweets and fruits of all kinds." Nugent professed herself "sicker than usual, at seeing such a profusion of eatables." 82

By the end of March, as her party reached St. Ann and yet another "immense second breakfast," Nugent had grown tired of Jamaican hospitality. She complained that one planter and Member of the Assembly who sat next to her at dinner "wore down my spirits, and put me out of patience, by speaking with his mouth full" and that almost "every man of the party was drunk, even to a boy of fifteen or sixteen." ${ }^{, 83}$ Still to come 
for Nugent were all of the parishes in the western part of the island, where she found, unsurprisingly, that "dinner was in the usual abundance." 84

Nugent did not, of course, encounter usual Jamaican mealtimes. ${ }^{85}$ The loaded tables marked and celebrated a visit by the governor and his wife. They were meant to impress. However, they also drew on creole rituals that reaffirmed white solidarity through corporate dining and male bonding. Nugent makes it apparent that these affairs were chances for militia officers and men to congregate, eat freely, and drink heavily. In accordance with those local traditions, the wealthy Jamaican landowners who arranged things around the Nugents tried to make a favorable impression on their guests as much by the quantity as by the quality and novelty of what they served. These meals, like everyday expressions of Jamaican hospitality, were types of gifts, and "gift-giving," in this context as in others, "was supposed to be a gracious, courteous, or friendly transaction, in which the obligation for return was not made explicit and gratitude was expected." ${ }^{86}$ The local elite expected the governor to appreciate their efforts and, without spelling it out, they hoped he would feel obliged to show them some solidarity in his dealing with the Jamaican Assembly and British government ministers. What the governor thought of the food, we cannot tell, but if he was impressed, then the meals achieved some political success.

Viewed more broadly, however, the meals were symptoms of white creole cultural failure. While George Nugent embarked on his inspections of Jamaica's military strength, Maria Nugent inspected its social mores and found them wanting. The food she encountered in Jamaica obviously interested and pleased her to a degree, and she very rarely complained about the quality or type of food that she was required to eat. ${ }^{87}$ Her cause for complaint was excessive self-indulgence on the part of white colonists, creole faults parodied by the soldier and artist Abraham James in his depiction of "Segar Smoking Society in Jamaica" (Figure 1). 
<INSERT FIGURE 1 (4 - Petley Fig1) here or nearby>

[Caption for Fig. 1:] Figure 1: Unknown engraver after Abraham James, "Segar Smoking Society in Jamaica" (etching and aquatint, 1802). Courtesy of the Lewis Walpole Library, Yale University. James's composition, created at around the same time that Maria Nugent was in Jamaica, lampoons the drinking habits and social mores of white colonial society.

Nugent came from a metropolitan society in which temperate behavior had come to be considered important. In step with religiously informed moves towards moderation, dining among the elites and middle classes of England and France had moved "from quantitative display to qualitative elaboration," more value being placed on the high quality of smaller amounts of food. In this new regime, "a sense of delicacy" (which was something to which Maria Nugent aspired) implied "a degree of restraint." By the turn of the nineteenth century slimmer bodies were the fashion, particularly among younger members of the British social elite. ${ }^{88}$ Moreover, a revolution in the gendered practices of dining saw renewed emphasis on family mealtimes and the role of wives as "the mistress of the house" as well as a new custom of seating men and women in alternate seats around the dining table. ${ }^{89}$ Concubinage and the scarcity of white women helped to make all of those markers of civility difficult to replicate in Caribbean slave societies. These changes in metropolitan dining practice made Jamaican mealtimes appear especially strange to metropolitan newcomers, at just the time that markers of colonial difference were coming under sharp critical scrutiny. A generation earlier, colonial divergence from metropolitan expectations might have been written off as mere creolean eccentricity. No longer; and Maria Nugent equated it with the moral bankruptcy of the planter class. 
She was certain that colonial society was flawed. "Every one seems solicitous to make money, and no one appears to regard the mode of acquiring it," she complained, before going on to note:

It is extraordinary to witness the immediate effect that the climate and habit of living in this country have upon the minds and manners of Europeans, particularly of the lower orders. In the upper ranks, they become indolent and inactive, regardless of everything but eating, drinking and indulging themselves, and are almost entirely under the domination of their mulatto favourites. In the lower orders they are the same with the addition of conceit and tyranny; considering the negroes as creatures formed merely to administer to their ease, and to be subject to their caprice; and I have found much difficulty to persuade those great people and superior beings, our white domestics, that the blacks are human beings, or have souls..$^{90}$

This account of West Indian manners and morals differs sharply to that of Janet Schaw. Some thirty years earlier, Schaw had celebrated white West Indian hospitality and accepted local foibles. Nugent, by contrast, criticized the hospitality that she received from planters, found local whites altogether less than "agreeable creatures," and produced a thoroughgoing critique of colonial slave society.

By the early nineteenth century, even many of those who took the side of the planter class in the abolition debates appeared to have doubts about white creole behavior. One proslavery writer commented that "primitive creolean customs" were "fast disappearing" among white colonists and "being superseded by the more polished manners of European life." ${ }^{91} \mathrm{He}$ also tried to reassure his readers that "semi-barbarous customs and practices" associated with concubinage had become less common. ${ }^{92}$ Such writers referred to the softening of other symptoms of creolean excess. "Hard drinking," explained one long-term resident of Jamaica, was "not quite so much the fashion here at 
present as in former times." ${ }^{, 93}$ Possibly aware of the trend towards more modest dining in the metropole, he commented on the attenuation of the more extravagant elements of Jamaican hospitality and hoped that time would see further "improvement in morals and manners." 94 Mrs Carmichael was certainly aware of this trend. In her proslavery travelogue, recalling a trip to the West Indies during the 1820 s, she argued that while to the casual observer - large communal meals were "a sure sign of the preference of the colonists for parade, ceremony, and expense," they were in fact a necessity, as planters were "unable to procure a moderate portion of meat at one time" and in fact "regretted this mode of entertaining." 95 This claim, though spurious, underlines how important it had become for defenders of the planters to demonstrate that colonial society had become more decorous and modest in its tastes.

Defenders of the slave system tried to argue that all elements of colonial behavior were harmonizing with metropolitan practice. This imperative for planters to demonstrate that they were reforming their behavior was symptomatic of the wider debate over slavery during the age of abolition. The proslavery lobby lost its propaganda war with the abolitionists as the British public - and British statesmen became convinced that Caribbean colonial societies were riddled with sin and that slavery was a corrupting influence on both its victims and their masters. In this context, a straightforward proslavery defense of colonial societies was untenable, and the planters and their allies were instead compelled to acknowledge that colonial societies, though evidently flawed, were undergoing rapid improvement. Before the 1830s, this rearguard defense against reform enjoyed some success with government ministers, who sought to compel slaveholders to ameliorate Caribbean slave societies while resisting abolitionist calls for thoroughgoing metropolitan state intervention in the colonies. Ultimately, however, it was too weak to rebut popular critiques of planter behavior or prevent imperial intervention to end slavery. 
IV

Problems of empire, problems of corruption, and problems of colonial difference loomed as large as the problem of slavery in debates about the Caribbean during the age of abolition. Caribbean colonists had created societies that were economically successful but otherwise disastrous, and the excessive freedoms and intemperate behavior of white West Indian men presented abolitionists and their sympathizers with a range of distasteful behavior to challenge. Slaveholding became their primary target, but they saw irreligion, concubinage, drunkenness, gluttony, and conspicuous displays of wealth as common ingredients in a colonial cocktail of vice and sin. White Jamaicans gorged sumptuously, but in the eyes of their critics, they did not eat well. They were gluttons who ate like cormorants and drank like porpoises, and no wonder they suffered from "general ill health" as a result. ${ }^{96}$ It was just one symptom of a deeper malaise infecting the colonial body politic.

In response, white West Indians and their supporters sought to resuscitate their flagging reputation by arguing that local society was undergoing improvement, but they failed to benefit from what James Belich describes as "a revolution in colonial thought," occurring around 1815, in which metropolitan commentators came to see white colonists in distant parts of the British world as people to be encouraged and admired. ${ }^{97}$ In nineteenth-century settler locations, such as the Cape Colony discussed by Alan Lester, the "domesticated family" provided the template and focus "for a new, British colonial culture" predicated on the transplantation of middle-class values and moral improvement. ${ }^{98}$ There and elsewhere, the idealization of the frontier homestead run by a wife devoted to childrearing, cleaning, and cooking became seared into mythologies of white settlement. By contrast, the enduring image of West Indian slaveholders is of immorality, gluttony, and the failure to create a "neo-Britain" in the tropics. ${ }^{99}$ As such, 
family, domestic arrangements, and mealtimes were a significant part of the planters' declining cultural reputation and political difficulties. Slaveholders in the British Caribbean could not project the image of a white nuclear family sat at table in the settler homestead. Neither could they adequately convince themselves or others that slavery was a domestic institution, enslaved people dependent extensions of a core family unit, as argued by planters in the US South during this period. ${ }^{100}$

The planters remained firmly on the back foot in the war of representation over slavery, unable to convince metropolitan observers that colonial slaveholders were capable of reforming their own behavior or of improving slave societies. Negative portrayals of British-Caribbean planters peaked during the early 1830s. In the aftermath of the violent white suppression of the 1831 Jamaican slave uprising, British audiences were exposed to a myriad of reports about white creoles' savagery, hostility towards true religion, and bad manners. At abolitionist rallies, in antislavery texts, and in parliamentary debates, these flaws and failings were laid bare as evidence of the necessity for an end to slaveholding. ${ }^{101}$ As he introduced the Emancipation Bill to parliament in May 1833, the Colonial Secretary reflected the prevailing mood, remarking that the institution of slavery had created a "perversion of moral feeling" in the minds of slave-owners. ${ }^{102}$

<INSERT FIGURE 2 (4 - Petley Fig2) here or nearby>

[Caption for Fig. 2:] Figure 2: C. J. Grant, "The Political Drama, no. 10: Slave Emancipation; or, John Bull Gulled out of Twenty Millions" (from a woodcut published c.1833). Courtesy of University College London Art Collections (EPC 8032).

Grant presents derogatory depictions of enslaved people and an unflattering portrait of the portly planter, on the far left of the image. Even those metropolitans who did not empathize with those enslaved in the 
Caribbean held negative views about planters, and in this instance corpulence appears to be associated with selfishness and avarice.

The image of an obese colonial planter in C. J. Grant's satirical cartoon commentary on emancipation - his hand outstretched to receive compensation money paid by the British public - epitomizes the diminished cultural status of the planters and its political ramifications (Figure 2). Although parts of the West India interest retained sufficient influence to win concessions, including compensation, from the British government, they were powerless to stop the end of slavery. In large part that was because Britons in the metropole no longer considered white colonials in the Caribbean to be worthy of their esteem or trust. Many appear to have agreed with Maria Nugent's view of white colonials as people with grotesque appetites and no sense of proportion. They might also have shared her ambivalence about slavery. Ultimately, it was distaste for a combination of slaveholder failings - including the brutal treatment of enslaved people, gluttonous eating, drunkenness, and disfavored sexual morals - that allowed abolitionists to push at an open door towards approval of their demands when they presented the problem of slavery as part of the bigger problem of corrupted and corrupting sections of the empire, which were rotten to the core, unpalatable to British tastes, incapable of self-improvement, and in need of reform from outside.

\section{Acknowledgements}

The author thanks Rachel Rich, Jane McDermid, and Richard Follett for their comments and suggestions as this article took shape.

\section{Notes on contributor}


Christer Petley's work has focused on slavery and abolition in the British Caribbean, particularly on slave-owners and the planter class. He is the author of Slaveholders in Jamaica (2009) and has published articles in Slavery and Abolition, The Journal of Imperial and Commonwealth History, and The Historical Journal. He is Chair of the UK Society for Caribbean Studies and teaches History at the University of Southampton.

\section{References}

Anon, An Account of Jamaica and its Inhabitants by a Gentleman Long Resident in the West Indies. London: G. Woodfall, 1808.

Bayly, C. A. Imperial Meridian: The British Empire and the World, 1780-1830. London: Longman, 1989.

Beckford, William. A Descriptive Account of the Island of Jamaica, 2 vols. London: T. and J. Egerton, 1790.

Belich, James. Replenishing the Earth: The Settler Revolution and the Rise of the Anglo-World. Oxford: Oxford University Press, 2009.

Bickham, Troy. Making Headlines: The American Revolution as seen through the British Press. DeKalb: Northern Illinois University Press, 2009.

Boyden, Peter B. “Nugent, Sir George, first baronet (1757-1849).” Oxford Dictionary of National Biography. Oxford: Oxford University Press, 2004.

Brown, Christopher Leslie. Moral Capital: Foundations of British Abolitionism. Chapel Hill: University of North Carolina Press, 2004.

Burnard, Trevor. “A Failed Settler Society: Marriage and Demographic Failure in Early Jamaica.” Journal of Social History 28, no. 1 (1994): 63-82. 
Burnard, Trevor. Mastery, Tyranny, and Desire: Thomas Thistlewood and his Slaves in the Anglo-Jamaican World. Chapel Hill: University of North Carolina Press, 2004.

Burnard, Trevor. “"Rioting in Goatish Embraces”: Marriage and Improvement in Early British Jamaica." The History of the Family 11, no. 4 (2006): 185-97.

Cargill-Raza, Rosemary. "Nugent, Maria, Lady Nugent (1770/71-1834).” Oxford Dictionary of National Biography. Oxford: Oxford University Press, 2004.

Carmichael, Mrs A.C. Domestic Manners and Social Condition of the White, Coloured, and Negro Population of the West Indies, 2 vols. London: Whittaker, Treacher and Co, 1834; first edition, 1833.

Clarkson, Thomas. An Essay on the Impolicy of the African Slave Trade in Two Parts (London: J. Phillips, 1788).

Colley, Linda. Britons: Forging the Nation, 1707-1837. London: Pimlico, 2003; first edition, 1992.

Conway, Stephen. The British Isles and the War of American Independence. Oxford: Oxford University Press, 2000.

Cumberland, Richard. The West Indian: A Comedy as it is performed at the Theatre Royal in Drury Lane. London: W. Griffin, 1771.

Cumberland, Richard. Memoirs of Richard Cumberland, Written by Himself, 2 vols. London: Lackington, Allen, and Co., 1807.

Cutting, John Browne. "A Succinct History of Jamaica." Preface to The History of the Maroons, 2 vols, R. C. Dallas. London: A. Strahan, 1803.

Davis, Natalie Zemon. The Gift in Sixteenth-Century France. Oxford: Oxford University Press, 2000.

Dirks, Nicholas B. The Scandal of Empire: India and the Creation of Imperial Britain. Cambridge MA: Harvard University Press, 2006. 
Edinburgh Magazine

Edwards, Bryan. The History, Civil and Commercial of the British Colonies in the West Indies, 2 vols. London: John Stockdale, 1793.

Gaspar, David Barry, "Slavery, Amelioration, and Sunday Markets in Antigua, 18231831." Slavery and Abolition 9, no. 1 (1998): 1-28.

Goldsmith, J. A Geographical View of the World: Embracing the Manners, Customs, and Pursuits, of every Nation. New York: William Reed, 1826.

Greene, Jack. P. "Liberty, Slavery and the Transformation of British Identity in the Eighteenth-Century West Indies.” Slavery and Abolition 21, no. 1 (2000): 1-31. Hall, Catherine. Civilising Subjects: Metropole and Colony in the English Imagination, 1830-1867. Cambridge: Polity, 2002.

Higman, B.W. Slave Populations of the British Caribbean, 1807-1834. Baltimore: Johns Hopkins University Press, 1984.

Heuman, Gad. Between Black and White: Race, Politics, and the Free Coloreds in Jamaica, 1792-1865. Westport: Greenwood Press, 1981.

Inventories, Jamaica Archives, Spanish Town, 1B/11/3.

Jamaica Courant.

Kennedy, Dane. Islands of White: Settler Society and Culture in Kenya and Southern Rhodesia, 1890-1939. Durham NC: Duke University Press, 1987.

Kriz, Kay Dian. Slavery, Sugar, and the Culture of Refinement: Picturing the British West Indies. New Haven and London: Yale University Press, 2008.

Lambert, David. White Creole Culture, Politics and Identity in the Age of Abolition. Cambridge: Cambridge University Press, 2005.

Lester, Alan. Imperial Networks: Creating Identities in Nineteenth-Century South Africa and Britain. London: Routledge, 2001. 
Long, Edward. The History of Jamaica, or a General Survey of the Antient and Modern State of the Island, 3 vols. London: T. Lowndes, 1774.

Long Manuscript, British Library, London, Add. Ms. I2, 435.

Marshall, Woodville, K. "Provision Ground and Plantation Labour in Four Windward Islands: Competition for Resources during Slavery.” In The Slaves' Economy: Independent Production by Slaves in the Americas, eds. Ira Berlin and Philip D. Morgan, 48-67. London: Frank Cass, 1991.

Mennell, Stephen. All Manners of Food: Eating and Taste in England and France from the Middle Ages to the Present. Chicago: University of Illinois Press, 1995.

“Ministerial Proposition for the Emancipation of Slaves." Hansard, 14 May 1833: 1193-262.

Mintz, Sidney W. Caribbean Transformations. New York: Columbia University Press, 1989; first edition, 1974.

Moreton, J. B. West India Customs and Manners: Containing Strictures on the Soil, Cultivation, Produce, Trade, Officers and Inhabitants. London: J. Parsons, 1793.

Murray, D. J. The West Indies and the Development of Colonial Government, 1801 1834. Oxford: Clarendon Press, 1965.

Naipaul, V. S. The Middle Passage: A Caribbean Journey. London: MacMillan, 2002; first edition, 1962.

Nechtman, Tillman W. Nabobs: Empire and Identity in Eighteenth-Century Britain. Cambridge: Cambridge University Press, 2010.

Nugent, Maria. Lady Nugent's Journal of her Residence in Jamaica from 1801 to 1805. Edited by Philip Wright. Kingston: University of the West Indies Press, 2002. O’Shaughnessy, Andrew Jackson. An Empire Divided: The American Revolution and the British Caribbean. Philadelphia: University of Pennsylvania Press, 2000. 
Petley, Christer. “'Home' and 'This Country': Britishness and Creole Identity in the Letters of a Transatlantic Slaveholder.” Atlantic Studies 6, no. 1 (2009): 43-61. Petley, Christer. Slaveholders in Jamaica: Colonial Society and Culture during the Era of Abolition. London: Pickering and Chatto, 2009.

Petley, Christer. “'Devoted Islands' and 'that Madman Wilberforce': British Proslavery Patriotism during the Age of Abolition." Journal of Imperial and Commonwealth History 39, no. 3 (2011): 393-495.

Pratt, Mary Louise. Imperial Eyes: Travel Writing and Transculturation. London: Routledge, 2008; first edition, 1992.

Ramsay, James. An Essay on the Treatment and Conversion of Slaves in the British Sugar Colonies. London: James Phillips, 1784.

Renny, Robert. An History of Jamaica with Observations on the Climate, Scenery, Trade, Productions, Negroes, Slave Trade, Diseases of Europeans, Customs, Manners, and Dispositions of the Inhabitants. London: J. Cawthorn, 1807.

Rozbicki, Michal J. The Complete Colonial Gentleman: Cultural Legitimacy in Plantation America. Charlottesville: University of Virginia Press, 1998.

Schaw, Janet. Journal of a Lady of Quality: Being the Narrative of a Journey from Scotland to the West Indies, North Carolina, and Portugal, in the Years 17741776. Edited by Evangeline Walker Andrews and Charles McClean Andrews. New Haven: Yale University Press, 1923.

Sheridan, Richard B. "The Crisis of Slave Subsistence in the British West Indies during and after the American Revolution." William and Mary Quarterly 23, no. 4 (1976): 615-41.

Sheridan, Richard B. Sugar and Slavery: An Economic History of the British West Indies, 1623-1775. Kingston: Canoe Press, 1994; first edition, 1974. 
Stewart, J. A View of the Past and Present State of the Island of Jamaica with Remarks on the Moral and Physical Condition of the Slaves and on the Abolition of Slavery in the Colonies. Edinburgh: Oliver and Boyd, 1823.

Strong, Roy. Feast: A History of Grand Eating. London: Jonathan Cape, 2002.

Trusler, John. The Honours of the Table, or, Rules for Behaviour during Meals. London, Literary Press, 1791).

Turner, Mary. "Slave Workers, Subsistence, and Labour Bargaining: Amity Hall, Jamaica, 1805-1832." In The Slaves' Economy: Independent Production by Slaves in the Americas, ed. Ira Berlin and Philip D. Morgan, 92-106. London: Frank Cass, 1991.

Wahrman, Dror. The Making of the Modern Self: Identity and Culture in EighteenthCentury England. New Haven and London: Yale University Press, 2004.

Walsh, Robert. An Appeal from the Judgments of Great Britain Respecting the United States of America. Philadelphia: Mitchell, Ames, and White, 1819.

Ward, J.R. "The British West Indies in the Age of Abolition, 1748-1815." In The Oxford History of the British Empire: The Eighteenth Century, ed. P. J. Marshall, 415-39. Oxford: Oxford University Press, 1998.

Wheeler, Roxann. The Complexion of Race: Categories of Difference in EighteenthCentury British Culture. Philadelphia: University of Pennsylvania Press, 2000.

Worcester, J. E. Sketches of the Earth and its Inhabitants, 2 vols. Boston: Cummings, Hilliard, and Co., 1823.

Wilberforce, William. A Practical View of the Prevailing Religious System of Professed Christians in the Higher and Middle Classes in this Country, Contrasted with Real Christianity. London: T. Cadell, 1797.

Wilberforce, William. A Letter on the Abolition of the Slave Trade Addressed to the Freeholders and other Inhabitants of Yorkshire. London: T. Cadell, 1807. 
Wilson, Kathleen. The Island Race: Englishness, Empire and Gender in the Eighteenth Century. London: Routledge, 2003.

Yeh, Sarah E. “"A Sink of All Filthiness': Gender, Family, and Identity in the British Atlantic, 1688-1763.” The Historian 68, no. 1 (2006): 66-88.

Young, Jeffrey Robert. Domesticating Slavery: The Master Class in Georgia and South Carolina, 1670-1837. Chapel Hill: University of North Carolina Press, 1999. Zacek, Natalie. Settler Society in the English Leewards, 1670-1776. Cambridge: Cambridge University Press, 2010.

\section{Notes}

${ }^{1}$ Nugent, Journal, 81.

${ }^{2}$ Naipaul went on to state that this materialistic "grossness" amounted to a history of "West Indian futility" and concluded: "The history of the islands can never be satisfactorily told. Brutality is not the only difficulty. History is built around achievement and creation; and nothing was created in the West Indies." Naipaul, The Middle Passage, 19-20.

${ }^{3}$ Colley, Britons, 350-60; Hall, Civilising Subjects, especially 69-115; Lambert, White Creole Culture, especially 1-40.

${ }^{4}$ Brown, Moral Capital; Wahrman, The Making of the Modern Self.

${ }^{5}$ Pratt, Imperial Eyes, 4.

${ }^{6}$ Inventories, Jamaica Archives.

${ }^{7}$ Edwards, History, vol. 2, 8-9. See also Renny, History of Jamaica, 213.

${ }^{8}$ See Petley, Slaveholders in Jamaica, 6.

${ }^{9}$ Burnard, "A Failed Settler Society." Enslaved people made up about $85 \%$ of the total population of the British Caribbean in 1815. For basic demographic data for different 
colonies, see Ward, “The British West Indies in the Age of Abolition”; Higman, Slave Populations, 77.

${ }^{10}$ Yeh, "A Sink of All Filthiness."

${ }^{11}$ Burnard, Mastery, Tyranny, and Desire, 244-50; Petley, Slaveholders in Jamaica, 1539.

${ }^{12}$ For comparable white behaviour in other colonial settings, see Lester, Imperial Networks, 76-77; Kennedy, Islands of White.

${ }^{13}$ Burnard, Mastery, Tyranny, and Desire, 249.

${ }^{14}$ For the period before the age of abolition, see Burnard, Mastery, Tyranny, and Desire, 79-83.

${ }^{15}$ Beckford, A Descriptive Account, vol. 1, 267. See also Edwards, History, vol. 2, 8.

${ }^{16}$ Moreton, West India Customs, 61.

${ }^{17}$ Renny, History of Jamaica, 217; Moreton, West India Customs, 60; Jamaica Courant, Thursday 6 October 1831.

${ }^{18}$ Renny, History of Jamaica, 216.

${ }^{19}$ Quoted in Renny, History of Jamaica, 323; Burnard, Mastery, Tyranny, and Desire, 81-83.

${ }^{20}$ Anon, An Account of Jamaica, 181.

${ }^{21}$ See Petley, Slaveholders in Jamaica, 35-52; Burnard, Mastery, Tyranny, and Desire, 82-83. Militia service was essential for all white men aged between sixteen and sixty. ${ }^{22}$ Long Manuscript. In the parish of Clarendon, white men outnumbered white women by a ratio of more than 3 to 1 (Burnard, Mastery, Tyranny, and Desire, 82). Clarendon was a rural parish, whereas St. James, though largely rural, included the large town of Montego Bay. White men predominated in rural areas where bachelors worked as bookkeepers and overseers on plantations and other properties. Higman, Slave Populations, 148-52. 
${ }^{23}$ This practice contributed to a rising population of free people of colour in BritishCaribbean slave societies such as Jamaica. See Heuman, Between Black and White, 3-8.

${ }^{24}$ Burnard, "Rioting in Goatish Embraces"; Yeh, "Sink of all Filthiness," 73; Petley, “"Home' and 'This Country'," 48-52. See also the article by Daniel Livesay in this issue, which charts changes in familial relations between white colonists and their mixed-race relatives.

${ }^{25}$ Moreton, West India Manners, 131-32.

${ }^{26}$ Renny, History of Jamaica, 329.

${ }^{27}$ On the work of enslaved people employed in domestic occupations such as purchasing and preparing food for slaveholders, see Higman, Slave Populations, 159$60,172-74,228,230-32$. In 1831 the Governor of Antigua noted that enslaved vendors were able to ensure the free population 'a regular and certain supply of Provisions' (quoted in Gaspar, "Slavery and Sunday Markets," 15). See also Mintz, Caribbean Transformations, 200.

${ }^{28}$ Sheridan, "The Crisis of Slave Subsistence"; Turner, "Slave Workers, Subsistence, and Labour Bargaining," quote at 92; Marshall, "Provision Ground and Plantation Labour."

${ }^{29}$ Rozbicki, The Complete Colonial Gentleman, 76-126. See also Yeh, 'A Sink of All Filthiness'; Greene, 'Liberty, Slavery and the Transformation of British Identity,' 1-2. ${ }^{30}$ Wilson, The Island Race, 13.

${ }^{31}$ Wheeler, The Complexion of Race, 226.

${ }^{32}$ Sheridan, Sugar and Slavery, 60-65; O'Shaughnessy, An Empire Divided, 12-17.

${ }^{33}$ See the article by Trevor Burnard in this issue.

${ }^{34}$ Nechtman, Nabobs. On scandal and concerns regarding the metropolitan influence of slavery and slaveholders, see Dirks, The Scandal of Empire, 32-34; Brown, Moral Capital, 95-101. 
${ }^{35}$ Cumberland, The West Indian, 5-6.

${ }^{36}$ Cumberland, The West Indian, 5.

${ }^{37}$ Cumberland, The West Indian, 8.

${ }^{38}$ Cumberland, Memoirs, vol. 1, 273-75.

${ }^{39}$ Schaw, Journal of a Lady of Quality. Schaw commented little on slavery, and appears to have no moral qualms regarding slaveholding. She depicted black people in grossly derogatory terms, claiming that the "nature of Negroes" made the whip necessary to plantation discipline and that an enslaved family transported from Africa displayed a relaxed "indifference" to their fate $(78,127-28)$.

${ }^{40}$ Schaw, Journal of a Lady of Quality, 95. Schaw noted that white men in Antigua were made "gay, luxurious and amorous" by the climate but was surprised by the abstemious customs of white Antiguan women, who rarely drank wine, and encouraged her hosts to join her in "a bumper of the best Madeira," which she thought must have "restorative" effects on the constitution in a hot climate. $(80-81,113)$.

${ }^{41}$ Schaw, Journal of a Lady of Quality, 95-100. As well as Antigua, Schaw visited St. Kitts, writing of the planters of there that the "elegance in which they live is not to be described, and whatever I have said of the table of Antigua is to be found here, even in a superior taste" (123).

${ }^{42}$ Schaw, 111-12

${ }^{43}$ Wheeler, The Complexion of Race, 225-28.

${ }^{44}$ Long, The History of Jamaica, vol. 2, 263, 265.

${ }^{45}$ Brown, Moral Capital, 36.

${ }^{46}$ Wahrman, Making of the Modern Self, 34. The quotes are from Wahrman's discussion of transgressive gendered identities in the metropole but are applicable to changing ideas about white West Indians and their behaviour.

${ }^{47}$ Wahrman, Making of the Modern Self, 115. 
${ }^{48}$ Brown, Moral Capital.

${ }^{49}$ See Bayly, Imperial Meridian; Murray, The West Indies and the Development of Colonial Government.

${ }^{50}$ See O’Shaughnessy, An Empire Divided, 238-45.

${ }^{51}$ Brown, Moral Capital, 113-53; Bickham, Making Headlines, 253.

${ }^{52}$ Wahrman, Making of the Modern Self, 223.

${ }^{53}$ Wahrman, Making of the Modern Self, 246, 264.

${ }^{54}$ Conway, British Isles and the War of American Independence, 354.

55 On slaveholders' sense of Britishness, see Petley, "Devoted Islands."

${ }^{56}$ Hall, Civilising Subjects, 107-115.

${ }^{57}$ Draper, The Price of Emancipation, 74. See also the article by Draper in this issue.

${ }^{58}$ On the often ambivalent metropolitan responses to Caribbean slaves, slavery and slaveholders see Kriz, Slavery, Sugar, and the Culture of Refinement.

${ }^{59}$ Edwards, History, vol. 2, 8.

${ }^{60}$ Cutting, 'A Succinct History of Jamaica', x, cxiv. Edinburgh Magazine, November 1794, 324-27. In the United States, Edwards was a trusted authority on white West Indian character. See Walsh, An Appeal, pp. 403-404. For direct and unattributed use of Edwards's words, see Worcester, Sketches of the Earth, vol. 1, 158; Goldsmith, A Geographical View of the World, 354.

${ }^{61}$ Renny, History, 216-17.

${ }^{62}$ Ramsay, An Essay on the Treatment and Conversion of Slaves, 147.

${ }^{63}$ Ramsay, An Essay on the Treatment and Conversion of Slaves, 254-55.

${ }^{64}$ Clarkson, An Essay on the Impolicy of the African Slave Trade, 102.

${ }^{65}$ Wilberforce, A Letter on the Abolition of the Slave Trade, 187-190.

${ }^{66}$ George Nugent (1757-1849), the illegitimate son of an unmarried Lieutenant in the British army, went to Charterhouse school before joining the army as an ensign and 
serving in the American War. He was promoted to Major-General in 1796 and served in high office in Ireland before his time in Jamaica and in India afterwards. He was a Member of Parliament for 26 years between 1806 and 1832. Maria Skinner Nugent (1770/71-1834) was the fifth daughter of Courtland Skinner, Advocate General of New Jersey, who remained a loyalist during the American War and left America to live in England after the Revolution. Maria married George Nugent in 1797. Boyden, "Nugent, Sir George"; Cargill-Raza, "Nugent, Maria".

${ }^{67}$ Nugent, Journal, 12-13. Nugent was bored by Jamaican society and wrote "I don't think any year of my life I ever read half as much as I have done since I came to this country" (40).

${ }^{68}$ Nugent, Journal, 12.

${ }^{69}$ Nugent, Journal, 11.

${ }^{70}$ Inventories, James Galloway, esquire, of St. James, 24 December 1833, vol. 150, f. 84; William Bellinger, esquire, of St. James, 13 August 1833, vol. 150, f. 64; John Cunningham, esquire, of St. James, 28 December 1812, vol. 121, f. 58; William Allen, esquire, of St. James, 5 December 1825, vol. 141, f. 156.

${ }^{71}$ Balcarres left his wife and family at home in England and appears to have engaged in the creole practice of keeping mistresses. Whilst at his country retreat, a pen three miles from Spanish Town, Nugent heard an “account of Lord B.'s domestic conduct, and his ménage here altogether." Almost certainly, Balcarres had kept a mistress at the pen, and Nugent was repelled by "horrid details" of this "profligate and disgusting scene" (Nugent, Journal, 38).

${ }^{72}$ Nugent, Journal, 10.

${ }^{73}$ Nugent, Journal, 14.

${ }^{74}$ Nugent, Journal, 48. Nugent remarked that she read Wilberforce's writing while in Jamaica but, frustratingly, she goes into no detail about what she read. It would be a 
mistake simply to assume that she read Wilberforce's writing on the abolition of the slave trade. Wilberforce's A Practical View of the Prevailing Religious System of Professed Christians in the Higher and Middle Classes in this Country, Contrasted with Real Christianity (London, 1797) went through seven new editions and was published in the British Isles and in the US before her Jamaican trip.

${ }^{75}$ Nugent, Journal, 45, 56.

${ }^{76}$ Nugent, Journal, 242.

${ }^{77}$ Nugent, Journal, 55-57.

${ }^{78}$ Nugent, Journal, 57-58.

${ }^{79}$ Nugent, Journal, 62.

${ }^{80}$ Nugent, Journal, 67.

${ }^{81}$ Nugent, Journal, 69.

${ }^{82}$ Nugent, Journal, 70.

${ }^{83}$ Nugent, Journal, 80-81.

${ }^{84}$ Nugent, Journal, 88. The tour ended on 24 April 1802 (97).

${ }^{85}$ On parting from the Nugents, Taylor had remarked that 'he must go home, and be abstemious, after so much feasting' (Nugent, Journal, 71).

${ }^{86}$ Davis, The Gift, 222.

${ }^{87}$ Her party ate a 'Creole-French' meal while being entertained by Taylor, which she remarked was "very good," and only on Lacovia estate in St. Elizabeth did she complain about the food: a "very course dinner" of beef and pork, arranged by the overseer of the property (Nugent, Journal, 66, 94).

${ }^{88}$ Mennell, All Manners of Food, 33-34, 37.

${ }^{89}$ See Strong, Feast, 289; Trusler, The Honours of the Table, 6.

${ }^{90}$ Nugent, Journal, 98.

${ }^{91}$ Stewart, A View of Jamaica, 168. 
92 Stewart, A View of Jamaica, 175.

${ }^{93}$ Anon, An Account of Jamaica, 198-99. Overlaps in style and content suggest that it is possible that the author of An Account of Jamaica was J. Stewart, author of A View of Jamaica.

${ }^{94}$ Anon, An Account of Jamaica, 181-83, 193-94, 206.

${ }^{95}$ Carmichael, Domestic Manners, vol. 1, 51. Carmichael also claimed that no more wine was drunk at dinner 'than is usually consumed at dinner parties in England' and that small 'social parties came more into vogue' during her time in the Caribbean (36, $41)$.

${ }^{96}$ Nugent, Journal, 81.

${ }^{97}$ Belich, Replenishing the Earth, 146-8, 152.

${ }^{98}$ Lester, Imperial Networks, 75.

${ }^{99}$ Belich, Replenishing the Earth, 127; Burnard, Mastery, Tyranny, and Desire, 271. For an analysis of the eighteenth-century Caribbean that emphasizes the transplantation by colonists of elements of metropolitan society and culture, see Zacek, Settler Society in the English Leeward Islands.

${ }^{100}$ Young, Domesticating Slavery.

${ }^{101}$ Petley, Slaveholders in Jamaica, 135-50; Hall, Civilising Subjects, 108-15, 310-11.

102 "Ministerial Proposition for the Emancipation of Slaves," 1215. 